\title{
Preparation and characterization of the RNase H domain of Moloney murine leukemia virus reverse transcriptase.
}

\section{AUTHOR(S):}

Nishimura, Kosaku; Yokokawa, Kanta; Hisayoshi, Tetsuro; Fukatsu, Kosuke; Kuze, Ikumi; Konishi, Atsushi; Mikami, Bunzo; Kojima, Kenji; Yasukawa, Kiyoshi

\section{CITATION:}

Nishimura, Kosaku ...[et al]. Preparation and characterization of the RNase H domain of Moloney murine leukemia virus reverse transcriptase.. Protein expression and purification 2015, 113: 44-50

\section{ISSUE DATE:}

2015-09

URL:

http://hdl.handle.net/2433/200910

\section{RIGHT:}

(c) 2015. This manuscript version is made available under the CC-BY-NC-ND 4.0 license

http://creativecommons.org/licenses/by-nc-nd/4.0/; The full-text file will be made open to the public on 30 September 2016 in accordance with publisher's 'Terms and Conditions for Self-Archiving'.; This is not the published version. Please cite only the published version.; この論文は出版社版でありません。引用の際には出版社版をご確認ご利用ください。 
1 Protein Expression and Purification

2

3 Preparation and characterization of the RNase $H$ domain of Moloney murine 4 leukemia virus reverse transcriptase

5

6 Kosaku Nishimura ${ }^{\mathrm{a}}$, Kanta Yokokawa ${ }^{\mathrm{a}}$, Tetsuro Hisayoshi ${ }^{\mathrm{a}}$, Kosuke Fukatsu ${ }^{\mathrm{a}}$, Ikumi

$7 \quad$ Kuze $^{\mathrm{a}}$, Atsushi Konishi ${ }^{\mathrm{a}}$, Bunzo Mikami ${ }^{\mathrm{b}}$, Kenji Kojima ${ }^{\mathrm{a}}$, Kiyoshi Yasukawa ${ }^{\mathrm{a}, *}$

8

$9{ }^{\mathrm{a}}$ Division of Food Science and Biotechnology, Graduate School of Agriculture, Kyoto

10 University, Sakyo-ku, Kyoto 606-8502, Japan

11 bivision of Applied Life Sciences, Graduate School of Agriculture, Kyoto University,

12 Gokasho, Uji, Kyoto 611-0011, Japan

* Corresponding author. Fax: +81-75-753-6265.

17 Abbreviations used: HIV-1, human immunodeficiency virus type 1; MMLV, Moloney

18 murine leukemia virus; RNase $\mathrm{H}$, ribonuclease $\mathrm{H}$; RT, reverse transcriptase; PAGE, polyacrylamide gel electrophoresis 
1 Moloney murine leukemia virus reverse transcriptase (MMLV RT) contains fingers, palm,

2 thumb, and connection subdomains as well as an RNase H domain. The DNA polymerase

3 active site resides in the palm subdomain, and the RNase $\mathrm{H}$ active site is located in the

4 RNase $\mathrm{H}$ domain. The RNase $\mathrm{H}$ domain contains a positively charged $\alpha$-helix called the

5 C helix $\left(\mathrm{H}^{594}\right.$ GEIYRRR $\left.{ }^{601}\right)$, that is thought to be involved in substrate recognition. In this

6 study, we expressed three versions of the RNase H domain in Escherichia coli, the wild-

7 type domain (WT) (residues Ile498-Leu671) and two variants that lack the regions containing the C helix (Ile593-Leu603 and Gly595-Thr605, which we called $\Delta$ C1 and $\Delta \mathrm{C} 2$, respectively) with a strep-tag at the $\mathrm{N}$-terminus and a deca-histidine tag at the Cterminus. These peptides were purified from the cells by anion-exchange, $\mathrm{Ni}^{2+}$ affinity, and Strep-Tactin affinity column chromatography, and then the tags were removed by proteolysis. In an RNase $\mathrm{H}$ assay using a 25-bp RNA-DNA heteroduplex, $\mathrm{WT}, \Delta \mathrm{C} 1$, and $\Delta \mathrm{C} 2$ produced RNA fragments ranging from 7 to 16 nucleotides (nt) whereas the fulllength MMLV RT (Thr24-Leu671) produced 14-20-nt RNA fragments, suggesting that elimination of the fingers, palm, thumb, and connection subdomains affects the binding of the RNase H domain to the RNA-DNA heteroduplex. The activity levels of WT, $\Delta \mathrm{C} 1$, and $\Delta \mathrm{C} 2$ were estimated to be $1 \%, 0.01 \%$, and $0.01 \%$ of full-length MMLV RT activity, indicating that the $\mathrm{C}$ helix is important, but not critical, for the activity of the isolated RNase H domain.

Keywords: Moloney murine leukemia virus; reverse transcriptase; RNase H activity; template-primer; thermostabilization 


\section{Introduction}

(1)

Retroviral reverse transcriptase (RT) possesses RNA- and DNA-dependent DNA polymerase as well as RNase $\mathrm{H}$ activities. Moloney murine leukemia virus (MMLV) RT is a 75-kDa monomer, comprised of the fingers (Thr24-Asp124 and Phe156-Ser195), palm (Ile125-Phe155 and Pro196-Glu275), thumb (Gly276-Leu338), and connection (Pro339-Asp468) subdomains and an RNase H domain (Arg469-Leu671). The active site of the DNA polymerase activity is located in the palm subdomain while the RNase $\mathrm{H}$ activity is in the RNase $\mathrm{H}$ domain $[1,2]$.

Due to its high catalytic activity and fidelity, MMLV RT is extensively used in cDNA synthesis [3]. Thermostability of DNA polymerase activity of MMLV RT increases by inactivating the RNase $\mathrm{H}$ activity by the mutation of the catalytically important residue, Asp524 [4-6]. The same strategy was successful to improve the thermostabilities of RTs from human immunodeficiency virus type-1 (HIV-1) [7] and avian myeloblastosis virus $(\mathrm{AMV})[5,8]$.

The whole structure of MMLV RT has not been determined yet. From the crystal of full-length MMLV RT (Thr24-Leu671), the structures of the fingers, palm, thumb, and connection subdomains (Thr24-Asn479) have been determined, but that of the RNase H domain has not [1, 9]. On the other hand, from the crystal of the isolated RNase H domain, its whole structure has been determined [10]. In that study, the RNase H domain variant lacking the polypeptide Ile593-Leu603 was successfully crystallized, while the wild-type RNase H domain was not [10]. The deleted polypeptide region, Ile593-Leu603, contains a positively charged $\alpha$-helix called the $C$ helix $\left(H^{594}\right.$ GEIYRRR $\left.{ }^{601}\right)$. In xenotropic murine leukemia virus-related virus (XMRV) RT, which has 95\% amino-acid sequence homology 
1 with MMLV RT, like MMLV RT, the structure of the isolated RNase H domain has been

2 determined whereas the whole structure has not [11-13]. Under these backgrounds, Das

3 et al. [1] and Cote et al. [2] have proposed the structural model of MMLV RT that the

4 RNase $\mathrm{H}$ domain is positioned far from the fingers/palm/thumb domain. However,

5 Pandey et al. have proposed another model that the polypeptide region Pro480-Arg506

6 of the RNase $\mathrm{H}$ domain, the structure of which has not been determined from the crystal

7 of the full-length molecule or the RNase $\mathrm{H}$ domain, interacts with the fingers/palm/thumb

8 subdomain, supporting the floor of the DNA polymerase active-site cleft. In MMLV RT,

9 it is difficult to clarify the interaction between the DNA polymerase and RNase $\mathrm{H}$ active

10 sites due to the lack of the crystal structure of the whole MMLV RT molecule.

The expression and purification of the isolated RNase H domains of MMLV RT in Esherichia coli were previolusly reported [1, 14-16]. They were expressed without tags $[14,16]$ or $S$-transferase fusion protein $[1,15]$. In this study, we describe expression, purification, and characterization of three versions of the RNase H domain of MMLV RT, the wild-type domain and the two C helix-deficient variants. They were expressed with N-terminal strep-tag and C-terminal deca-histidine tag in E. coli, purified from the cells, and then the tags were removed by proteolysis. The enzyme preparations thus obtained were characterized and compared with full-length MMLV RT.

\section{Materials and methods}

Materials

$\left[\gamma_{-}{ }^{32} \mathrm{P}\right] \mathrm{dATP}(111 \mathrm{TBq} / \mathrm{mmol})$ was purchased from PerkinElmer (Waltham, MI). 
1 Oligonucleotides were from Fasmak (Atsugi, Japan). The RT concentration was

2 determined by the method of Bradford [17] using Protein Assay CBB Solution (Nacalai

3 Tesque, Kyoto, Japan) with bovine serum albumin (Nacalai Tesque) as standard.

$5 \quad$ Plasmids

6

$7 \quad$ We previously constructed the expression plasmid for C-teminally (His) 6 -tagged

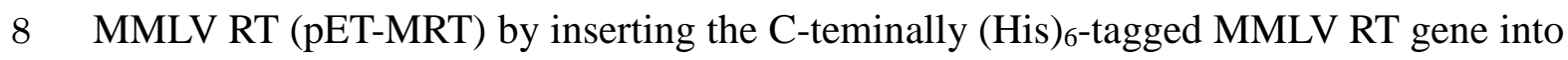
9 the NdeI and EcoRI sites of pET-22b(+) plasmid (Merck Bioscience, Tokyo, Japan). The 10 expression plasmids for the wild-type RNase H domain (Ile498-Leu671) (WT), its 11 variant lacking Ile593-Leu603 ( $\Delta \mathrm{C} 1)$, and its variant lacking Gly595-Thr605 ( $\Delta \mathrm{C} 2)$, 12 each with C-teminal (His)6 tag (pET22b-RNaseH-WT, pET22b-RNaseH- $\Delta$ C1, and 13 pET22b-RNaseH- $\Delta \mathrm{C} 2$, respectively) were constructed as follows. Site-directed mutagenesis was carried out using the following nucleotide primers 5'CAACACAACTGCCATATGATCCTGGCCGAA-3’ (497Nde) and 5’TTCGGCCAGGATCATATGGCAGTTGTGTTG-3’ (497Nde_cp) to change the nucleotide sequence CTTGAT encoding ${ }^{496} \mathrm{Leu}^{497}$ Asp into a NdeI recognition sequence CATATG. The resuting plasmid, pET-MRT(Nde), was digested with NdeI and self-ligated to produce the expression plasmid for WT, pET22b-RNaseH-WT. The 391-bp fragment (F1) was amplified from pET22b-RNaseH-WT using the following nucleotide primers

and 5'-

GCCTTCTGATGTGAGATGGGCAGTAGCAAA-3' (DelI593-L603rev-4), and the 247bp fragment (F2) was amplified using the following nucleotide primers 5'- 
HISB). The 608-bp fragment was amplified using the nucleotide primers Pro and MRTHISB from the mixture of F1 and F2, digested with the restriction enzymes $X b a \mathrm{I}$ and EcoRI, and inserted in pET-22b(+) digested with XbaI and EcoRI to produce the expression plasmid for $\Delta \mathrm{C} 1$, pET22b-RNaseH- $\Delta \mathrm{C} 1$. The expression plasmid for $\Delta \mathrm{C} 2$, pET22b-RNaseH- $\Delta \mathrm{C} 1$ was constructed by the same method but using the nucleotide primers 5’-CTCTTTGCCTTCTGATGTGAGATGGGCAGT-3’ (DelG595-T605rev-4) and 5'-ACTGCCCATATCCATTCAGAAGGCAAAGAG-3’ (DelG595-T605for-4) instead of DelI593-L603rev-4 and DelI593-L603for-4, respectively. and a C-teminal (His) 10 tag (pET52b-RNaseH-WT, pET52b-RNaseH- $\Delta$ C1, and pET52bRNaseH- $\Delta$ C2, respectively) were constructed as follows. The 550-bp fragment was amplified with the following nucleotide primers 5'TTTTGGTACCTTGATGTCCTGGCCGAAGCC-3’’ (497Kpn) and 5’TTTTGAGCTCGAGGAGGGTAGAGGTGTC-3' (671Sac) from pET22b-RNaseH-WT, and the 517-bp fragments were amplified from 497Kpn and 671Sac from pET22bRNaseH- $\Delta \mathrm{C} 1$ or pET22b-RNaseH- $\Delta \mathrm{C} 2$. These three fragments were digested with the restriction enzymes KpnI and SacI, and inserted in pET-52b(+) (Merck Bioscience) to produce pET52b-RNaseH-WT, pET52b-RNaseH- $\Delta$ C1, and pET52b-RNaseH- $\Delta$ C2, respectively.

Expression and purification of recombinant RNase H domain 
1 with either pET52b-RNaseH-WT, pET52b-RNaseH- $\Delta$ C1, or pET52b-RNaseH- $\Delta$ C2. The

2 overnight culture of the transformants (20 ml) was added to 2,000 $\mathrm{ml}$ of $\mathrm{LB}$ broth and in

3 a 2-liter flask and incubated at $37^{\circ} \mathrm{C}$ under vigorous aeration by air-pump. When $O D_{660}$

4 reached $0.6-0.8,0.5 \mathrm{~mL}$ of $0.5 \mathrm{M}$ IPTG was added and growth was continued at $30^{\circ} \mathrm{C}$ for

$54 \mathrm{~h}$. After centrifugation at $10,000 \times g$ for $10 \mathrm{~min}$, the cells were harvested, suspended

6 with $20 \mathrm{ml}$ of $0.02 \mathrm{M}$ potassium phosphate (pH 7.2), $2.0 \mathrm{mM}$ dithiothreitol (DTT), $10 \%$

7 glycerol (buffer A) containing $1 \mathrm{mM}$ phenylmethylsulfonyl fluoride (PMSF) and

8 disrupted by sonication. After centrifugation at $20,000 \times g$ for $40 \mathrm{~min}$, the supernatant

9 was collected and applied to a column [25 mm (inner diameter) $\times 120 \mathrm{~mm}$ ] packed with

Toyopearl DEAE-650M gel (Tosoh, Tokyo, Japan), previoulsy equilibrated with buffer A.

The bound RNase $\mathrm{H}$ domain was eluted with buffer A containing $100 \mathrm{mM} \mathrm{NaCl}$ and applied to a HisTrap column, previously equilibrated with $50 \mathrm{mM}$ Tris-HCl (pH 8.3), 200 mM KCl, 2.0 mM DTT, 10\% glycerol (buffer B). The bound RNase H domain was eluted with buffer B containing $250 \mathrm{mM}$ imidazole and applied to a Strep-Tactin Superflow column (IBA, Göttingen, Germany), previously equilibrated with $100 \mathrm{mM}$ Tris-HCl (pH 8.0), $150 \mathrm{mM} \mathrm{NaCl}, 1 \mathrm{mM}$ EDTA (buffer C). The bound RNase $\mathrm{H}$ domain was eluted with buffer C containing $2.5 \mathrm{mM}$ desthiobiotin, 50\% glycerol. Two mg of the obtained RNase $\mathrm{H}$ domain was subjected to the digestion by 10 units of HRV 3C protease (Accelagen, San Diego, CA) to cleave the strept tag and 50 units of thrombin (GE Healthcare) to cleave the (His) $)_{10}$ tag in $12.5 \mathrm{ml}$ of $40 \mathrm{mM}$ Tris- $\mathrm{HCl}$ (pH 7.5), $120 \mathrm{mM}$ $\mathrm{NaCl}, 10 \%$ glycerol at $4^{\circ} \mathrm{C}$ for $36 \mathrm{~h}$ (buffer $\mathrm{D}$ ). Then, the solution was three-fold diluted by adding $25 \mathrm{ml}$ of water and further incubated at $4^{\circ} \mathrm{C}$ for $36 \mathrm{~h}$. The digest was applied to a HisTrap column, previously equilibrated with buffer B. The RNase H domain without tags had weak binding ability to a HisTrap column, and it was collected from a HisTrap 
1 column by eluting with buffer B containing $50 \mathrm{mM}$ imidazole. In this buffer condition,

2 the RNase $\mathrm{H}$ domain with deca-histidine tag was not eluted. The obtained RNase $\mathrm{H}$

3 domain without tags was applied to a PD-10 column packed with a Sephadex G-25 (GE

4 Healthcare), previously equilibrated with $20 \mathrm{mM}$ Tris-HCl (pH 7.0), containing $200 \mathrm{mM}$

$5 \mathrm{NaCl}, 2.0 \mathrm{mM}$ DTT, and 10\% glycerol. The column was washed and eluted with the same

6 buffer. Purified RNase $\mathrm{H}$ domain was stored at $-80^{\circ} \mathrm{C}$ before use.

7

SDS-PAGE

9

SDS-PAGE of the RNase $\mathrm{H}$ domain was carried out in a $12.5 \%$ polyacrylamide gel under reducing conditions. Proteins $(1.2 \mu \mathrm{g})$ were reduced by treatment with $2.5 \%(\mathrm{v} / \mathrm{v})$ of 2-mercaptoethanol at $100^{\circ} \mathrm{C}$ for $10 \mathrm{~min}$, and then applied onto the gel. A constant current of $40 \mathrm{~mA}$ was applied for $40 \mathrm{~min}$. After electrophoresis, proteins were stained with Coomassie Brilliant Blue R-250. The molecular mass marker kit consisting of rabbit muscle phosphorylase B (97.2 kDa), bovine serum albumin (66.4 kDa), hen egg white ovalbumin (44.3 kDa), and bovine carbonic anhydrase $(29.0 \mathrm{kDa})$ was purchased from Takara Bio Inc (Otsu, Japan).

\section{CD spectroscopy}

The CD spectra of the RNase H domain was measured with a 2-mm cell using a J820 spectropolarimeter (Jasco, Tokyo, Japan) under the following condition: spectral

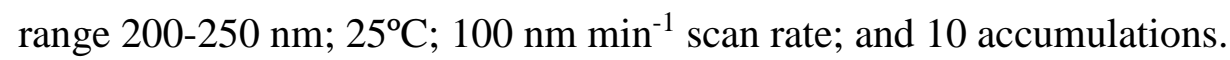


Fluorescence-based RNase H assay

Fluorescence-based RNase H activity assay was carried out according to the method by Parniak et al [18]. Briefly, an RNA/DNA hybrid (named R18/D18) was prepared by mixing the 3'-fluorescein modified 18-nucleotide (nt) RNA 5'GAUCUGAGCCUGGGAGCU-3' (R18) and 5'-dabcyl-modified complementary 18-nt DNA (D18) with a molar ratio of 1.0:1.2 in $50 \mathrm{mM}$ Tris-HCl buffer (pH 8.0) containing $60 \mathrm{mM} \mathrm{KCl}$ followed by the incubation at room temperature for $30 \mathrm{~min}$. The RNase $\mathrm{H}$ reaction was carried out in $50 \mathrm{mM}$ Tris- $\mathrm{HCl}$ buffer ( $\mathrm{pH}$ 8.0) containing $60 \mathrm{mM} \mathrm{KCl,} 5.0$ $\mathrm{mM} \mathrm{MgCl}, 0.25 \mu \mathrm{M}$ R18/D18 (the concentration is expressed as that of R18), and indicated concentrations of the RNase $\mathrm{H}$ domain or the full-length MMLV RT at $37^{\circ} \mathrm{C}$. An aliquot $(800 \mu \mathrm{l})$ was taken from the reaction mixture at a predetermined time and added to $0.5 \mathrm{M}$ EDTA $(160 \mu \mathrm{l})$. The fluorescence spectra of the reaction products were measured with a Shimadzu RF-5300PC fluorescence spectrophotometer (Shimadzu, Kyoto, Japan) under the following conditions: excitation wavelength, $490 \mathrm{~nm}$; spectral range $500-600 \mathrm{~nm} ; 25^{\circ} \mathrm{C} ; 120 \mathrm{~nm} \min ^{-1}$ scan rate; and 3 accumulations. In each measurement, the control baseline was obtained with the corresponding buffer in the absence of protein.

Radioisotope-based RNase H assay

Radioisotope-based RNase H activity assay was carried out according to the method by Álvarez et al [19]. Briefly, an RNA/DNA hybrid (named R25/D25) was prepared by mixing 5'-[ $\left.{ }^{32} \mathrm{P}\right]$-labelled 25-nt RNA 5'-AUGUAUAGCCCUACCAGCAUUCTGG-3' 
1 (R25) and unlabelled complementary 25-nt DNA (D25) by the method above described.

2 The RNase $\mathrm{H}$ reaction $(40 \mu \mathrm{l})$ was carried out in $50 \mathrm{mM}$ Tris- $\mathrm{HCl}(\mathrm{pH} 8.0)$ buffer,

3 containing $50 \mathrm{mM} \mathrm{KCl}, 0.1 \mathrm{mM} \mathrm{MgCl}_{2}, 20 \mathrm{nM} \mathrm{R} 25 / \mathrm{D} 25$, and indicated concentrations

4 of the RNase $\mathrm{H}$ domain or the full-length MMLV RT at $37^{\circ} \mathrm{C}$. An aliquot (4 $\left.\mu \mathrm{l}\right)$ was taken

5 from the reaction mixture at a predetermined time and added to $4 \mu \mathrm{l}$ of sample-loading

6 buffer (10 mM EDTA, 90\% (v/v) formamide, $3 \mathrm{mg} / \mathrm{ml}$ xylene cyanol $\mathrm{FF}, 3 \mathrm{mg} / \mathrm{ml}$

7 bromophenol blue, and $50 \mu \mathrm{M}$ 31D/21D. (31D/21D was prepared by mixing unlabelled 31-nt DNA 5’-TTTTTTTTTAGGATACATATGGTTAAAGTAT-3’ (D31) and unlabelled complementary complementary 21-nt DNA 5’-ATACTTTAACCATATGTATCC-3’(D21) by the method above described and used as a carrier DNA.) The RNA fragments of the reaction products were analyzed by denaturing $20 \%$ polyacrylamide gel electrophoresis followed by image scanning with a BAS-2500 scanner (Fujifilm, Tokyo, Japan) using the program Multi Gauge version 2.2 (Fujifilm).

\section{Results}

Expression and purification of the RNase $H$ domain

We initially attempted to express the wild-type RNase $\mathrm{H}$ domain (WT) (Ile498-Leu671) and the two C helix-deficient variants lacking Ile593-Leu603 ( $\Delta$ C1) and Gly595-Thr605 ( $\Delta \mathrm{C} 2)$, with C-terminal (His)6 tags at the C-terminus. We constructed three expression plasmids, pET22b-RNaseH-WT, pET22b-RNaseH- $\Delta \mathrm{C} 1$, and pET22bRNaseH- $\Delta \mathrm{C} 2$ that contain the T7 promoter, an ATG initiation codon, a 540- or 507-bp sequence encoding 180 or 169 amino acids comprising the intact or C helix-deficient 
1 RNase H domain (Ile498-Leu671), and a (His)6 tag, and a stop codon. SDS-PAGE

2 analysis of the soluble fractions of the E. coli transformants showed a 20-kDa protein

3 band corresponding to WT or a $19-\mathrm{kD}$ a protein band corresponding to $\Delta \mathrm{C} 1$ and $\Delta \mathrm{C} 2$ (data

4 not shown). However, the RNase $\mathrm{H}$ domain could not be purified to homogeneity because

5 several contaminating proteins, presumably C-terminal (His) 6 -tagged RNase $\mathrm{H}$ domain

6 degradation products, could not be completely removed (data not shown).

Next we attempted to express $\mathrm{WT}, \Delta \mathrm{C} 1$, and $\Delta \mathrm{C} 2$ with both an $\mathrm{N}$-terminal strep tag

8 and a C-terminal (His) 10 tag. We constructed three expression plasmids, pET52b-

9 RNaseH-WT, pET52b-RNaseH- $\Delta$ C1, and pET52b-RNaseH- $\Delta$ C2 (Fig. 1), that contain

10 the T7 promoter, an ATG initiation codon, a 711- or 678-bp sequences encoding 237 or

11206 amino acids comprising a strep-tag, an HRV 3C protease recognition site, the intact

12 or C helix-deficient RNase H domain, a thrombin recognition site, and a (His) 10 tag, and

13 a stop codon. SDS-PAGE analysis of the soluble fractions showed a 25-kDa protein band

14 corresponding to WT in the transformants with pET52b-RNaseH-WT (lane 2 in Fig. 2A)

and a 24-kDa protein band corresponding to $\Delta \mathrm{C} 1$ or $\Delta \mathrm{C} 2$ in the transformants with pET52b-RNaseH- $\Delta \mathrm{C} 1$ or pET52b-RNaseH- $\Delta \mathrm{C} 2$, respectively (data not shown).

To purify WT, $\Delta \mathrm{C} 1$, and $\Delta \mathrm{C} 2$, we used anion-exchange chromatography as the first step, the $\mathrm{Ni}^{2+}$-sepharose chromatography as the second step, and the Strep-Tactin affinity chromatography as the third step. At each step, each fraction was tested for the presence of the $25-\mathrm{kDa}$ or $24-\mathrm{kDa}$ protein band by SDS-PAGE, and the active fractions were pooled based on coomassie staining. The SDS-PAGE analysis showed that the active fractions from the WT purification exhibited 25-kDa protein bands (Fig. 2A), and the purified preparations of WT, $\Delta \mathrm{C} 1$, and $\Delta \mathrm{C} 2$ exhibited 25-kDa or 24-kDa protein bands (Fig. 2B). In Fig. 2B, the 50 or $55 \mathrm{kDa}$ faint bands were also observed; however their 
1 orgins were unknown. Then, the $\mathrm{N}$-terminal strep tag and C-terminal (His) 10 tag were

2 removed by successive proteolysis with HRV 3C protease and thrombin, respectively.

3 After proteolysis, the WT preparation exhibited a single 22-kDa protein band (Fig. 2C),

4 the $\Delta \mathrm{C} 1$ and $\Delta \mathrm{C} 2$ preparations exhibited single 21-kDa protein bands (data not shown),

5 and the protein bands corresponding to the 50 or $55 \mathrm{kDa}$ faint bands obserbed in Fig. 2B

6 were not observed (Fig. 2C for WT and and data not shown for $\Delta \mathrm{C} 1$ and $\Delta \mathrm{C} 2$ ). From the

72 L cultures, $0.5-1.0 \mathrm{mg}$ of purified WT, $\Delta \mathrm{C} 1$, and $\Delta \mathrm{C} 2$ were obtained. In $20 \mathrm{mM}$ Tris-

$8 \mathrm{HCl}(\mathrm{pH}$ 7.0), $200 \mathrm{mM} \mathrm{NaCl}, 2.0 \mathrm{mM}$ DTT, and 10\% glycerol, WT, $\Delta \mathrm{C} 1$, and $\Delta \mathrm{C} 2$ with

9 tags could be concentrated to $1-2 \mathrm{mg} / \mathrm{ml}$, whereas without tags, these proteins could be concentrated to $10 \mathrm{mg} / \mathrm{ml}$ (data not shown), indicating that the removing of the tags increased the solubility. change of the isolated RNase $\mathrm{H}$ domain, we made spectroscopic analyses. UV spectroscopy showed that purified WT, $\Delta \mathrm{C} 1$, and $\Delta \mathrm{C} 2$ exhibited spectra with a deep trough at approximately $250 \mathrm{~nm}$ and a peak at $275 \mathrm{~nm}$ (Fig. 3B for WT and data not shown for $\Delta \mathrm{C} 1$ and $\Delta \mathrm{C} 2)$. $\mathrm{CD}$ spectroscopy showed that purified $\mathrm{WT}, \Delta \mathrm{C} 1$, and $\Delta \mathrm{C} 2$ exhibited negative ellipticities at 202-250 nm with peaks at approximately $208 \mathrm{~nm}$ and $222 \mathrm{~nm}$ (Fig. 3B for WT and data not shown for $\Delta \mathrm{C} 1$ and $\Delta \mathrm{C} 2)$. No appreciable changes were observed in UV and CD) spectra, suggesting that $\Delta \mathrm{C} 1$, and $\Delta \mathrm{C} 2$ did not suffer from any global or drastic structural changes by the deletion.

Characterization of the RNase H domain 
1 fluorescence-based RNase H assay. An RNA/DNA hybrid (called R18/D18) consisting

2 of a 3'-fluorescein modified 18-nt RNA (R18) and a 5'-dabcyl-modified 18-nt DNA

3 (D18) was used as the substrate (Fig. 4A). R18/D18 is designed to emit strong

4 fluorescence when R18 is cleaved at a site close to the 3' end, and the fluorescein-labeled

5 RNA fragment dissociates from the complementary DNA strand. Figure 4B shows the

6 difference in the fluorescence spectra of R18/D18 before and after the reaction. Based on

7 the previous report, the $\mathrm{MgCl}_{2}$ concentration was set at $5.0 \mathrm{mM}$ [19]. When R18/D18 was

8 incubated without the full-length RT or the isolated RNase $\mathrm{H}$ domain for $30 \mathrm{~min}$, there

9 was no change in the fluorescence spectra. When R18/D18 was incubated with $50 \mathrm{nM}$ HIV-1 RT or $1.8 \mu \mathrm{M}$ WT for $30 \mathrm{~min}$, the fluorescence increased with the peak at $515 \mathrm{~nm}$. When R18/D18 was incubated with $\Delta \mathrm{C} 1$ or $\Delta \mathrm{C} 2$ for $30 \mathrm{~min}$, no fluorescence increase was observed. These results suggest that WT has RNase $\mathrm{H}$ activity and $\Delta \mathrm{C} 1$ and $\Delta \mathrm{C} 2$ do not. a radioisotope-based RNase H assay. An RNA/DNA hybrid (R25/D25) consisting of a 5'[ $\left.{ }^{32} \mathrm{P}\right]$-labelled 25-nt RNA (R25) and an unlabeled complementary DNA (D25) was used as the substrate (Fig. 5A). After the RNase H reaction, the RNA reaction products were analyzed by denaturing PAGE. First we examined the effects of $\mathrm{MgCl}_{2}$ concentration on the RNase $\mathrm{H}$ activity of WT and found that reactions containing $0.1-0.2 \mathrm{mM}$ yielded relatively higher amounts of products than those containing other concentrations (0-15 $\mathrm{mM}$ ) (data not shown). Thus, $0.1 \mathrm{mM}$ was used in subsequent experiments.

Figure 5B shows the denatured PAGE analysis of the products obtained from the reaction under various conditions. Unreacted R25/D25 showed only a single 25-nt RNA band. When R25/D25 was incubated with 30 nM full-length MMLV RT, 16-20-nt bands were detected at $15 \mathrm{~s}$, and 14-17-nt bands were detected at $10 \mathrm{~min}$. When R25/D25 was 
1 incubated with $30 \mathrm{nM} \mathrm{WT}$, only a 25-nt band was detected at both $15 \mathrm{~s}$ and $10 \mathrm{~min}$. When

2 R25/D25 was incubated with 1.0 or $10 \mu \mathrm{M}$ WT, only a 25-nt band was detected at $15 \mathrm{~s}$,

3 whereas various bands (mainly 7-16-nt bands) were detected at $10 \mathrm{~min}$. This indicated that the cleavage pattern of WT was different from that of the full-length MMLV RT and that the activity of WT was considerably weaker than that of the full-length MMLV RT. When R25/D25 was incubated with $\Delta \mathrm{C} 1$ or $\Delta \mathrm{C} 2$, various bands (mainly 7-16-nt bands) were only detected at a $10 \mu \mathrm{M}$ and 10 min. Under all other reaction conditions tested, only the uncleaved 25-nt band was detected. This indicated that although the activities of $\Delta \mathrm{C} 1$ and $\Delta \mathrm{C} 2$ were weaker than that of $\mathrm{WT}$, the cleavage patterns were the same as that of WT.

Figure 5C compares the time courses of the cleavage patterns obtained in the reactions with $30 \mathrm{nM}$ full-length MMLV RT, $1 \mu \mathrm{M}$ WT, and $10 \mu \mathrm{M} \Delta \mathrm{C} 1$ and $\Delta \mathrm{C} 2$. The results of a densitometry trace of each band were shown in Fig. S1. In full-length MMLV RT, 10-20-nt bands were detected, in which the amount of the 17-nt band was the highest at 5-30 min and that of the 14-nt band was the highest at 60 and $120 \mathrm{~min}$. In WT, $\Delta \mathrm{C} 1$, and $\Delta \mathrm{C} 2,7-20$-nt bands were detected, in which the amount of the 7- or 10-nt band was higher than those of other bands. The rates of the decrease in the 25-nt bands in the reaction with WT, $\Delta \mathrm{C} 1$, and $\Delta \mathrm{C} 2$ were $30 \%, 3 \%$, and $3 \%$ of full-length MMLV RT, respectively. Based on these enzyme concentrations (30 nM for full-length MMLV RT, 1 $\mu \mathrm{M}$ for $\mathrm{WT}$, and $10 \mu \mathrm{M}$ for $\Delta \mathrm{C} 1$, and $\Delta \mathrm{C} 2$ ), the activities of $\mathrm{WT}, \Delta \mathrm{C} 1$, and $\Delta \mathrm{C} 2$ were roughly estimated to be $1 \%, 0.01 \%$, and $0.01 \%$ of full-length MMLV RT activity, respectively. 
1

2

3

4

5

\section{Discussion}

(

(

(

$$
\text { and C-terminal deca-histidine tag. The use of two tags has an advantage as it allows the }
$$
removal of degraded products using one of the tags. In our initial attempt to express the RNase H domain with only a C-terminal (His)6-tag, the degraded products could not be completely removed, as described in the Results section. In addition, the removing of the tags was important because it increased the solubility. Based on the SDS-PAGE (Fig. 2) and spectroscopic analysis (Fig. 3) results, we considered the purity of the RNase $\mathrm{H}$ preparations to be sufficient for use in structural and functional analysis.

The DNA in the 25-bp RNA/DNA heteroduplex used in the radioisotope-based RNase $\mathrm{H}$ assay lacks the primer 3'-terminus (Fig. 5A). The reaction with full-length MMLV RT produced 17-20-nt RNA fragments (Fig. 5B), indicating that the position at which the RNA strand of the RNA/DNA hybrid is cleaved is 17-20 bp upstream of the 3'-terminus of the primer. This is the same position as previoulsly reported in assays of full-length MMLV RT using RNA/DNA hybrids with primer 3'-termini [20, 21]. This suggests that the DNA polymerase active site binds to the RNA/DNA hybrid in a similar manner whether it has the primer 3'-terminus or not.

Unlike the full-length MMLV RT, WT, $\Delta \mathrm{C} 1$, and $\triangle \mathrm{C} 2$ produced RNA fragments mainly ranging from 7 to $16 \mathrm{nt}$ in length (Fig. 5B). We speculate a possible mechanism for the generation of fragments of these lengths as follows: For the full-length MMLV $\mathrm{RT}$, the position at which the RNase $\mathrm{H}$ active site binds to the RNA strand of an RNA/DNA hybrid is predetermined, whereas for the isolated RNase $\mathrm{H}$ domains, the active site binding position is not; thus the cleavage site by the isolated RNase $\mathrm{H}$ domain 
1 is different from that by the full-length MMLV RT. This suggests that elimination of the

2 fingers, palm, thumb, and connection subdomains affects the binding of the RNase $\mathrm{H}$ domain to an RNA/DNA heteroduplex.

In this study, we expressed WT as well as $\Delta \mathrm{C} 1$ and $\Delta \mathrm{C} 2$ because the crystal structure of MMLV RT $\triangle \mathrm{C} 1$ has been determined [1] and the structures of XMRV RT WT and $\Delta \mathrm{C} 2$ have been determined [22, 23]. In the RNase $\mathrm{H}$ assay using a fluorescent substrate, WT exhibited activity, whereas $\Delta \mathrm{C} 1$ and $\Delta \mathrm{C} 2$ did not (Fig. 4). However, in the RNase H assay using a radioactive substrate, all three exhibited the activity (Fig. 5). Therefore, we concluded that the $\mathrm{C}$ helix is not critical for the activity of the isolated MMLV RT RNase $\mathrm{H}$ domain. However, the RNase $\mathrm{H}$ activities of $\Delta \mathrm{C} 1$ and $\Delta \mathrm{C} 2$ were only $10 \%$ of WT activity (Fig. 5C), suggesting that the $C$ helix is important for activity. Similar results have been reported for full-length MMLV RT, and the C helix has been shown to be important for both DNA polymerase and RNase H activities [22, 23].

Unlike the MMLV RT RNase H domain, the RNase H domain of HIV-1 RT does not contain the C helix, and the isolated HIV-1 RT RNase H domain lacks activity [24-27]. Interestingly, insertion of a basic loop near at the active site of the isolated RNase $\mathrm{H}$ domain generated weak activity in the presence of $\mathrm{Mn}^{2+}$ [28]. Recently, Permanasari et al. reported that addition of bacterial RNase HI or HII substrate binding domain to the isolated RNase $\mathrm{H}$ domain also resulted in weak activity in the presence of $\mathrm{Mn}^{2+}$ [29]. These results supports the notion that the $\mathrm{C}$ helix is important for RNase $\mathrm{H}$ activity.

E. coli RNase HI contains the C helix [30] whereas the RNase H domains of MMLV RT and HIV-1 RT are C helix-deficient. Comparison of the structure of $\Delta \mathrm{C} 1$ (PDB accession codes SHB5) with that of E. coli RNase HI (3AA2) suggests that the C helix of the RNase H domain of MMLV RT is positioned similary to that of E. coli RNase HI. 
1 Comparison of the structure of $\Delta \mathrm{C} 1$ with a complex containing the isolated HIV-1 RT

2 RNase H domain and an RNA/DNA heteroduplex (1HYS) suggests that the C helix in the

3 RNase $\mathrm{H}$ domain of MMLV RT interacts with the RNA strand of the RNA/DNA

4 heteroduplex. Therefore, the $\mathrm{C}$ helix is thought to contribute to substrate recognition, as

$5 \quad$ reported previously by Nowotny et al. [31].

6 In conclusion, we expressed the RNase $\mathrm{H}$ domain of MMLV RT in E. coli and

7 purified it to homogeneity. Characterization of the recombinant proteins suggested that

8 the $\mathrm{C}$ helix is involved in the substrate recognition and that the fingers, palm, thumb, and

9 connection subdomains are involved in positioning of the cleavage sites in the RNA strand

10 of an RNA/DNA heteroduplex. These recombinant RNase $\mathrm{H}$ domain proteins might be

11 suitable for use in structural and functional analyses to elucidate the mechanisms of

12 thermostabilization of MMLV RT through site-directed mutagenesis. An extensive study

13 is currently underway to prepare crystals of WT, $\Delta \mathrm{C} 1$, and $\Delta \mathrm{C} 2$, with and without a

14 mutation of the catalytic Asp (Asp524).

\section{Acknowledgments}

(no. 21580110) from the Japan Society for the Promotion of Science and the Salt Science Researh Foundation.

\section{References}

[1] D. Das, M.M. Georgiadis, The crystal structure of the monomeric reverse 
transcriptase from Moloney murine leukemia virus, Structure 12 (2004) 819-829.

[2] M.L. Coté, M.J. Roth, Murine leukemia virus reverse transcriptase: structural comparison with HIV-1 reverse transcriptase, Virus Res. 134 (2008) 186-202.

[3] A.R. Kimmel, S.L. Berger, Preparation of cDNA and the generation of cDNA libraries: overview, Methods Enzymol. 152 (1987) 307-316.

[4] M.L. Kotewicz, J.M. D’Alessio, K.M. Driftmier, K.P. Blodgett, G.F. Gerard, Cloning and overexpression of Moloney murine leukemia virus reverse transcriptase in Escherichia coli, Gene 35 (1985) 249-258.

[5] G.F. Gerard, R.J. Potter, M.D. Smith, K. Rosenthal, G. Dhariwal, J. Lee, D.K. Chatterjee, The role of template-primer in protection of reverse transcriptase from thermal inactivation, Nucleic Acids Res. 30 (2002) 3118-3129.

[6] M. Mizuno, K. Yasukawa, K. Inouye, Insight into the mechanism of the stabilization of Moloney murine leukaemia virus reverse transcriptase by eliminating RNase H activity, Biosci. Biotechnol. Biochem. 74 (2010) 440-442.

[7] K. Nishimura, M. Shinomura, A. Konishi, K. Yasukawa, Stabilization of human immunodeficiency virus type 1 reverse transcriptase by site-directed mutagenesis, Biotechnol. Lett. 35 (2013) 2165-2175.

[8] A. Konishi, K. Yasukawa, K. Inouye, Improving the thermal stability of avian myeloblastosis virus reverse transcriptase $\alpha$-subunit by site-directed mutagenesis, Biotechnol. Lett. 34 (2012) 1209-1215.

[9] D. Lim, G.G. Gregorio, C. Bingman, E. Martinez-Hackert, W.A. Hendrickson, S.P. Goff, Crystal structure of the Moloney murine leukemia virus RNase H domain, J. Virol. 80 (2006) 8379-8389.

[10] E. Nowak, W. Potrzebowski, P.V. Konarev, J.W. Rausch, M.K. Bona, D.I. Svergun, 
J.M. Bujnicki, S.F.J. Le Grice, M. Nowotny, Structural analysis of monomeric retroviral reverse transcriptase in complex with an RNA/DNA hybrid, Nucleic Acid Res. 41 (2013) 3874-3887.

[11] D. Zhou, S. Chung, M. Miller, S.F.J. Le Grice, A. Wlodawer, Crystal structures of the reverse transcriptase-associated ribonuclease $\mathrm{H}$ domain of xenotropic murine leukemia-virus related virus, J. Struct. Biol. 177 (2012) 638-645.

[12] J.H. Kim, S. Kang, S.-K. Jung, K.R. Yu, S.J. Chung, B.H. Chung, R.L. Erikson, B.Y. Kim, S.J. Kim, Crystal structure of xenotropic murine leukaemia virus-related virus (XMRV) ribonulease H, Biosci. Rep. 32 (2012) 455-463.

[13] V. Barrioluengo, Y. Wang, S.F.J. Le Grice, L. Menéndez-Arias, Intrinsic DNA synthesis fidelity of xenotropic murine leukemia virus-related virus reverse transcriptase, FEBS J. 279 (2012) 1433-1444.

[14] N. Tanese, S.P. Goff, Domain structure of the Moloney murine leukemia virus reverse transcriptases: mutational analysis and separate expression of the DNA poluymerase and RNase H activities, Proc. Natl. Acad. Sci. USA 85 (1988) 17771781.

[15] S.J. Schultz and J.J. Champoux, RNase H domain of Moloney murine leukemia virus reverse transcriptase retains activity byt requires the polymerase domain for specificity, J. Virol. 70 (1996) 8630-8638.

[16] E.R. Gooden and S. Marqusee, Folding the ribonulcease H domain of Moleney murine leukemia virus reverse transcriptase requires mtal binding or a short Nterminal extension, Proteins 33 (1998) 135-143.

[17] M.M. Bradford, A rapid and sensitive method for the quantitation of microgram quantities of protein utilizing the principle of protein-dye binding, Anal. Biochem. 
72 (1976) 248-254.

[18] M.A. Parniak, K.L. Min, S.R. Budihas, S.F.J. Le Grice SFJ, J.A. Beutler, A fluorescence-based high throughput screening assay for inhibitors of human immunodeficiency virus-1 reverse transcriptase-associated ribonuclease $\mathrm{H}$ activity, Anal. Biochem. 322 (2003) 33-39.

[19] M. Álvarez, T. Matomoros, L. Menéndez-Arias, Increased thermostability and fidelity of DNA synthesis of wild-type and mutant HIV-1 group O reversetranscriptases, J. Mol. Biol. 392 (2009) 872-884.

[20] S.J. Schultz, M. Zhang, J.J. Champoux, Sequence, distance, and accessibility are determinats of 5'-end-directed cleavages by retroviral RNases H, J. Biol. Chem. 281 (2006) 1943-1955.

[21] S.J. Schultz, M. Zhang, J.J. Champoux, Preferred sequence within a defined cleavage window specify DNA 3' end-directed cleavages by retroviral RNases H, J. Biol. Chem. 284 (2009) 32225-32238.

[22] P.L. Boyer, H.-Q. Gao, P. Frank, P.K. Clark, S.H. Hughes, The basic loop of the RNase H domain of MLV RT is important both for RNase H and for polymerase activity, Virology 282 (2001) 206-213.

[23] D. Lim, M. Orlova, S.P. Goff, Mutations of the RNase H C helix of the Moloney murine leukemia virus reverse transcriptase reveal defects in polypurine tract recognition, J. Virol. 76 (2002) 8360-8373.

[24] Z. Hostomsky, Z. Hostomska, G.O. Hudson, E.W. Moomaw, B.R. Nodes, Reconstitution in vitro of RNase $\mathrm{H}$ activity by using purified N-terminal and Cterminal domains of human immunodeficiency virus type 1 reverse transcriptase, Proc. Natl. Acad. Sci. USA 88 (1994) 1148-1152. 
1 [25] J.L. Keck, S. Marqusee, Substitution of a highly basic helix/loop sequence in the RNase $\mathrm{H}$ domain of human immunodeficiency virus reverse transcriptase restored its $\mathrm{Mn}^{2+}$-dependent RNase H activity, Proc. Natl. Acad. Sci. USA 92 (1995) 27402744.

[26] T. Tadokoro, S. Kanaya, Ribonuclease H: molecular diversities, substrate binding domains, and catalytic mechamism of the prokaryotic enzymes, FEBS J. 276 (2009) 1482-1493.

[27] S.J. Stahl, J.D. Kaufman, S. Vikić-Topić, R.J. Crouch, P.T. Wingfield, Construction of an enzymatically active ribonuclese $\mathrm{H}$ domain fo human immunodeficiency virus type 1 reverse transcriptase, Protein Eng. 7 (1994) 1103-1108.

[28] E.-D.Permanasari, K. Yasukawa, S. Kanaya, Enzymatic activities of RNase H domains of HIV-1 reverse transcriptase with substrate binding domains of bacterial RNase H1 and H2, Mol. Biotechnol. in press (2015)

[29] S. Kanaya, A. Kohara, Y. Miura, S. Sekiguchi, S. Iwai, H. Inoue, E. Ohtsuka, M. Ikehara, Identification of the amino acid residues involved in an active site of Escherichia coli ribonuclease H by site-directed mutagenesis, J. Biol. Chem. 265 (1990) 4615-4621.

[30] S. Kanaya, C. Katsuda-Nakai, M. Ikehara, Importance of the positive charge cluster in Escherichia coli ribonuclease $\mathrm{H} 1$ for the effective binding of the substrate, J. Biol. Chem. 266 (1991) 11621-11627.

[31] M. Nowotny, S.A. Gaidamakov, R. Ghirlando, S.M. Cerritelli, R.J. Crouch, W. Yang, Structure of human RNase H1 compexed with an RNA/DNA hybrid: insight into HIV reverse transcription, Mol. Cell. 28 (2007) 264-276. 


\section{$1 \quad$ Figure legends}

2

3 Fig. 1. Expression plasmids for the RNase H domain. The structures of pET-RNaseH-WT, 4 pET-RNaseH- $\Delta \mathrm{C} 1$, and pET-RNaseH- $\Delta \mathrm{C} 2$ are shown. The “498”, “671”, and asterisk 5 indicate Ile498, Leu671, and the termination codon. The amino acid sequences of strep 6 tag, HRV 3C protease recognition site, thrombin recognition site, and (His) $)_{10}$ are 7 underlined.

9 Fig. 2. SDS-PAGE analysis. CBB-stained 12.5\% SDS-polyacryl amide gel is shown. (A)

10 Active fractions of each purification stage for the wild-type RNase $\mathrm{H}$ (WT). Lanes: marker proteins (lane 1), soluble fractions of the total extracts (lane 2), active fractions of ion-exchange chromatography (lane 3), $\mathrm{Ni}^{2+}$ affinity chromatography (lane 4), and StrepTactin affinity chromatogaraphy (lane 5). (B) Purified enzyme preparations with Nterminal strep tag and C-terminal (His) ${ }_{10}$ tag. Lanes: marker proteins (lane 1), WT (lane 2), RNaseH- $\Delta \mathrm{C} 1$ (lane 3), and RNaseH- $\Delta \mathrm{C} 2$ (lane 4). (C) Purified WT preparations. Lanes: marker proteins (lane 1), before removal of fused tags (lane 2), and after removale of fused tags (lane 3).

Fig. 3. UV and CD spectroscopic analysis of purified WT. (A) UV spectra. (B) CD spectra.

Fig. 4. RNase $\mathrm{H}$ activity of the RNase $\mathrm{H}$ domain using a fluorescent substrate. (A) Sequences of the RNA-DNA hybrid, R18/D18. (B) Fluorescence spectra of R18/D18 with excitation at $490 \mathrm{~nm}$. The reaction was carried out with either of $50 \mathrm{nM}$ HIV-1 RT, 1.8 $\mu \mathrm{M} W \mathrm{WT}, 1.8 \mu \mathrm{M} \Delta \mathrm{C} 1$, and $1.8 \mu \mathrm{M} \Delta \mathrm{C} 2$ for $30 \mathrm{~min}$ at $\mathrm{pH} 8.0$ at $37^{\circ} \mathrm{C}$. 
2 Fig. 5. RNase $\mathrm{H}$ activity of the RNase $\mathrm{H}$ domain using a radioactive substrate. (A)

3 Sequences of the RNA-DNA hybrid, R25/D25. (B, C) Patterns of denatured PAGE. The

4 enzyme concentrations were $30 \mathrm{nM}$ for full-length MMLV RT, $1 \mu \mathrm{M}$ for WT, and $10 \mu \mathrm{M}$

5 for $\Delta \mathrm{C} 1$ and $\Delta \mathrm{C} 2$. The reaction times were $15 \mathrm{~s}$ and $10 \mathrm{~min}(\mathrm{~B})$ and $15 \mathrm{~s}, 30 \mathrm{~s}, 1 \mathrm{~min}, 5$

$6 \mathrm{~min}, 15 \mathrm{~min}, 30 \mathrm{~min}, 1 \mathrm{~h}$, and $2 \mathrm{~h}(\mathrm{C})$. The reaction was carried out with $1.8 \mu \mathrm{M} \mathrm{WT}$,

$7 \quad \Delta \mathrm{C} 1$, or $\Delta \mathrm{C} 2$ for $30 \mathrm{~min}$ at $\mathrm{pH} 8.0$ at $37^{\circ} \mathrm{C}$.

8

9

10 


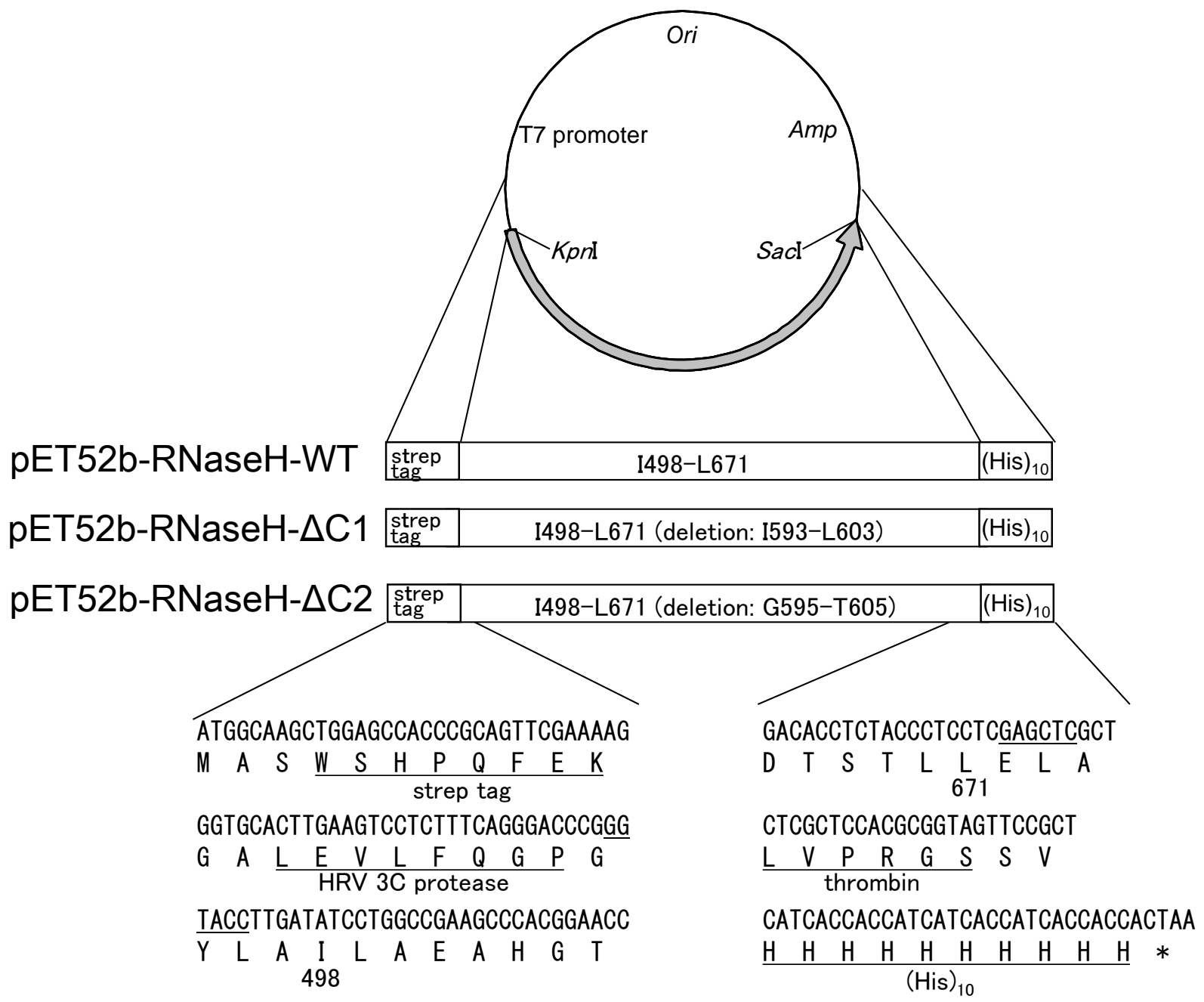

Fig. 1 
A

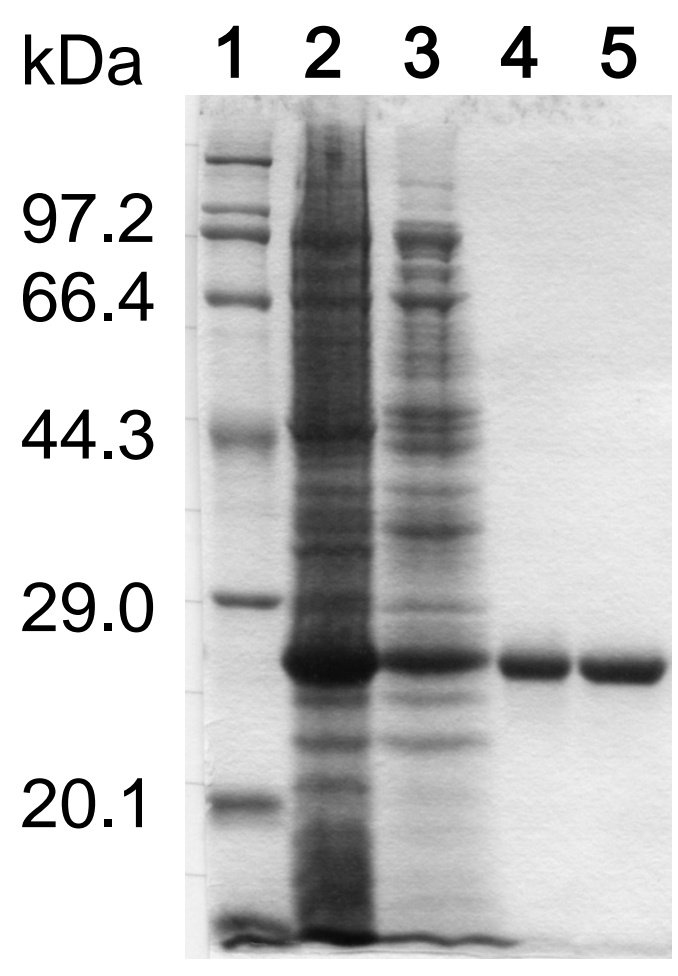

B

$\mathrm{kDa} 1234$

C

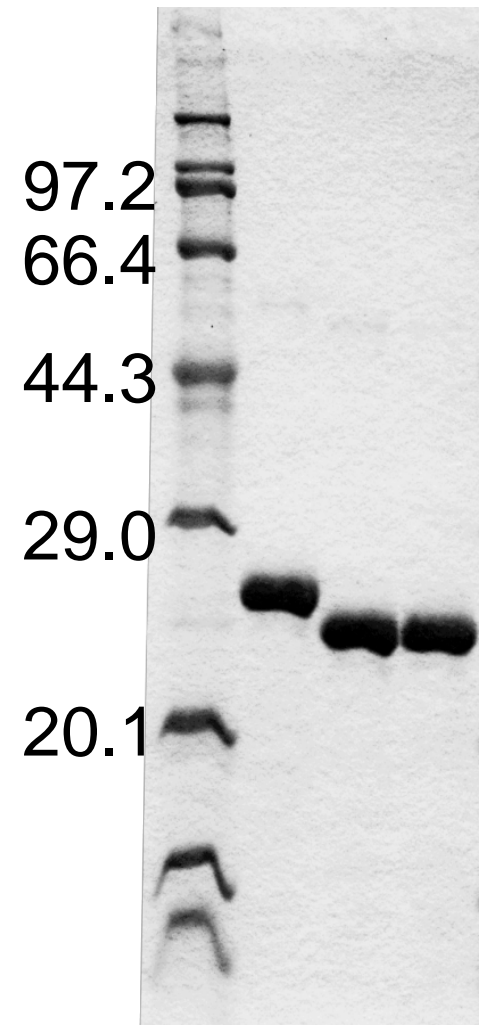

$\begin{array}{llll}\mathrm{kDa} & 1 & 2 & 3\end{array}$

97.2

66.4

44.3

29.0

20.1

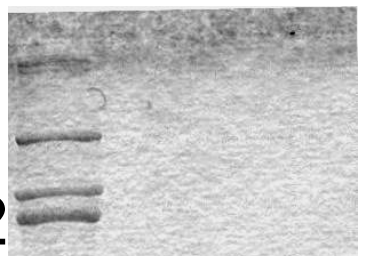

Fig. 2 


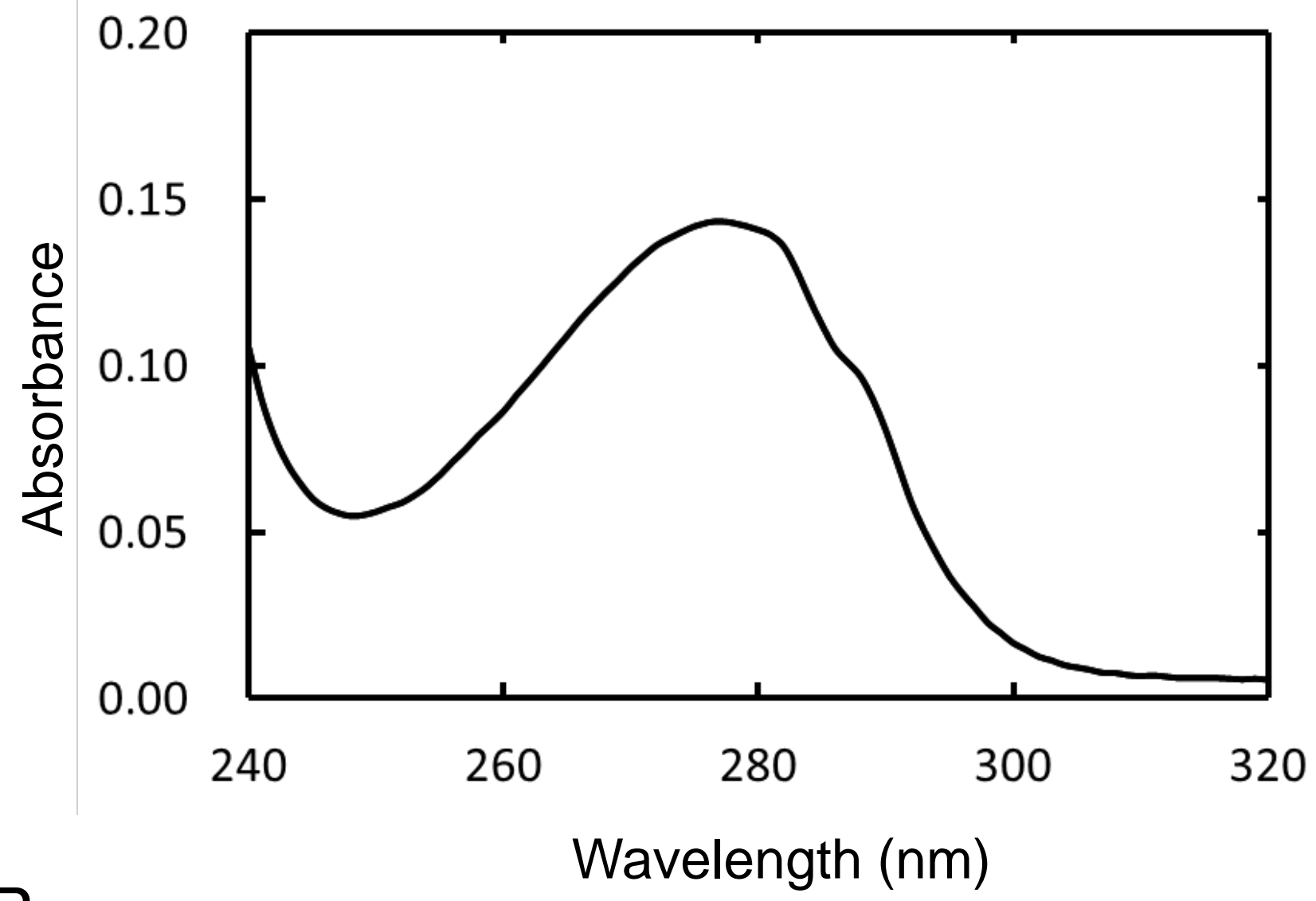

B

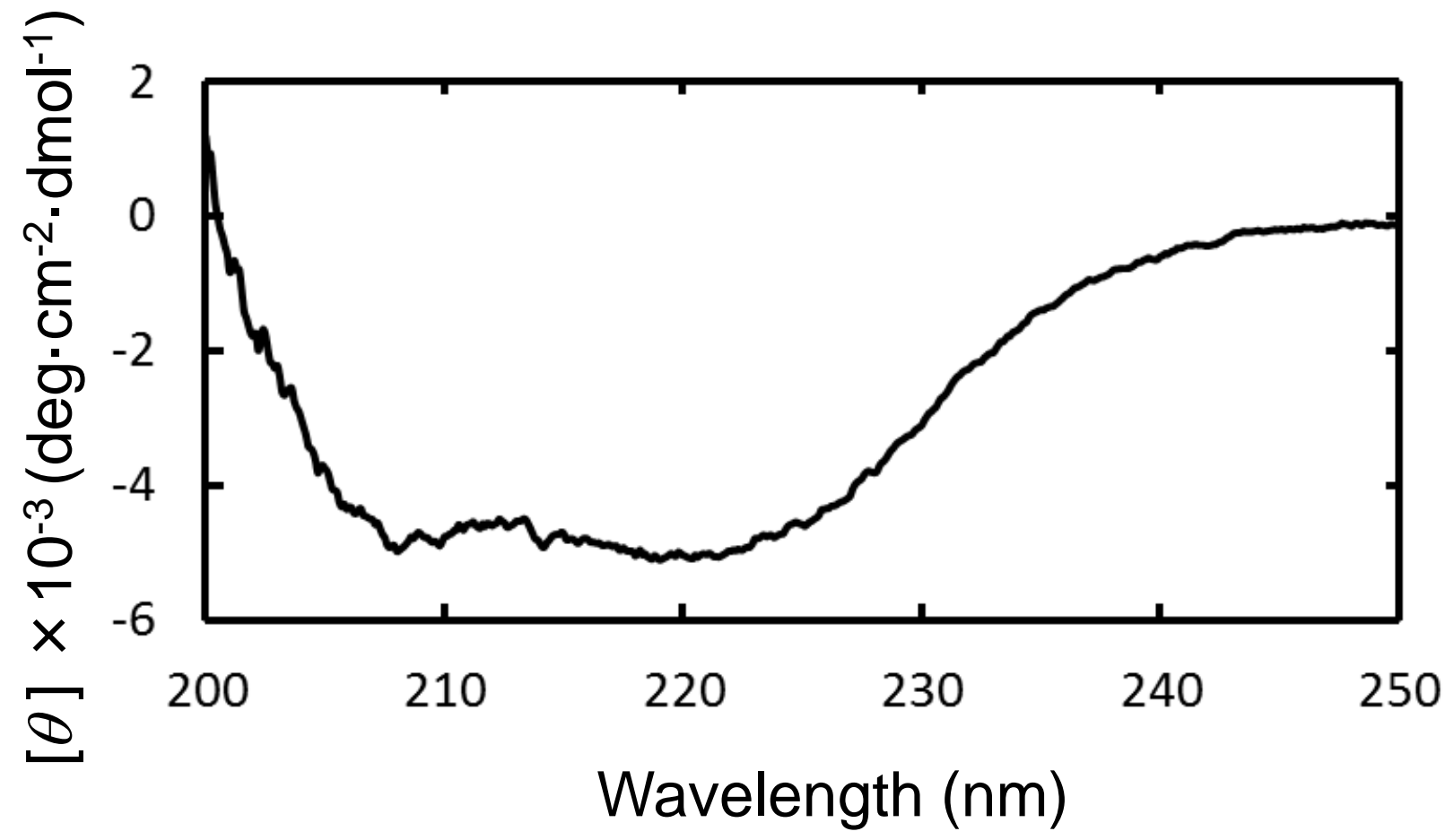

Fig. 3 
R18: 5' -GAUCUGAGCCUGGGAGCU-f I uor esce in-3'

D18: 3' -CTAGACTCGGACCCTCGA-DABCYL-5'

$B$

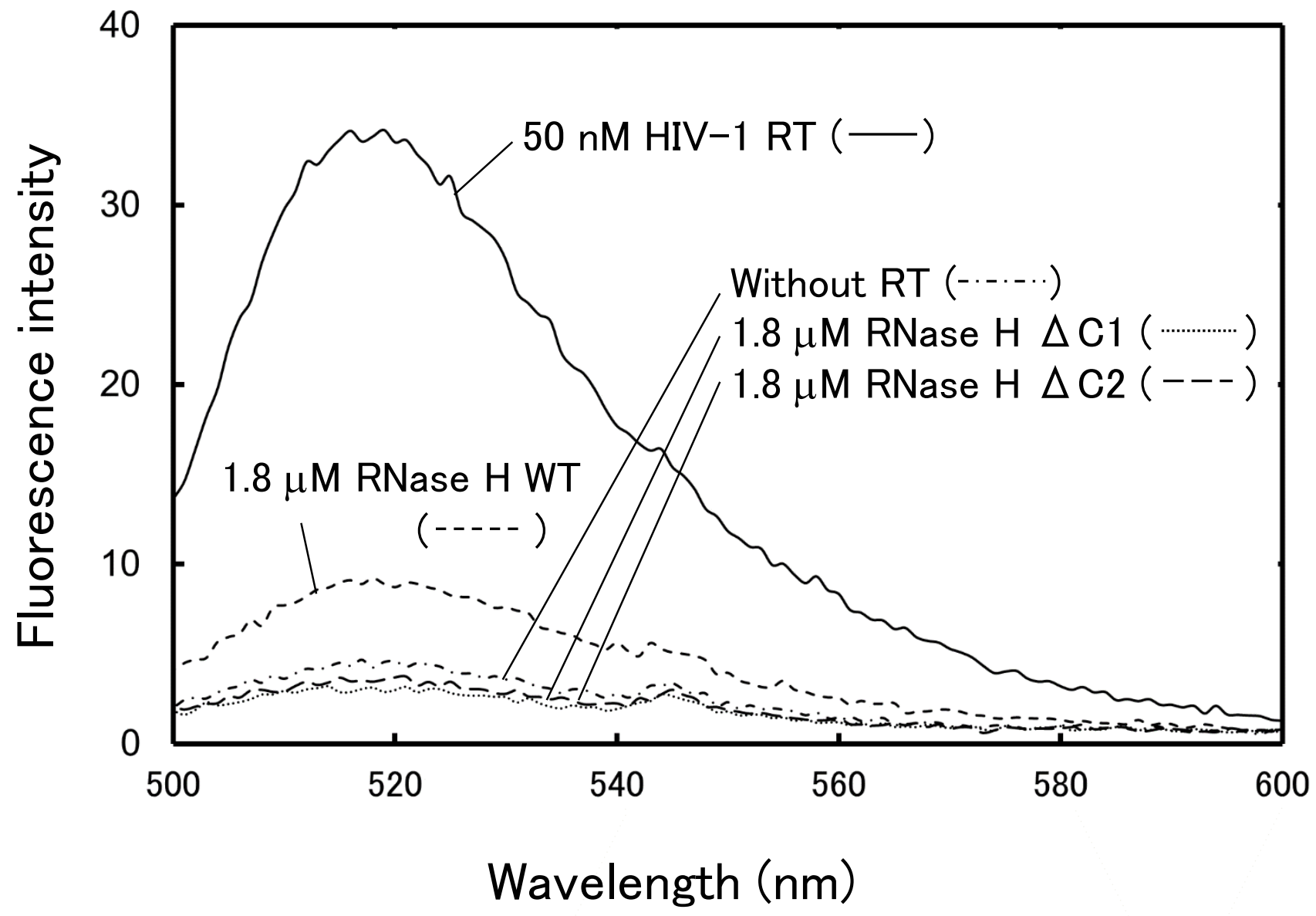

Fig. 4 
R25: 5' - [32P]AUGUAUAGCCCUACCAGCAUUCTGG-3 ' D25: $3^{\prime \prime}$ - TACATATCGGGATGGTCGTAAGACC-5"

B

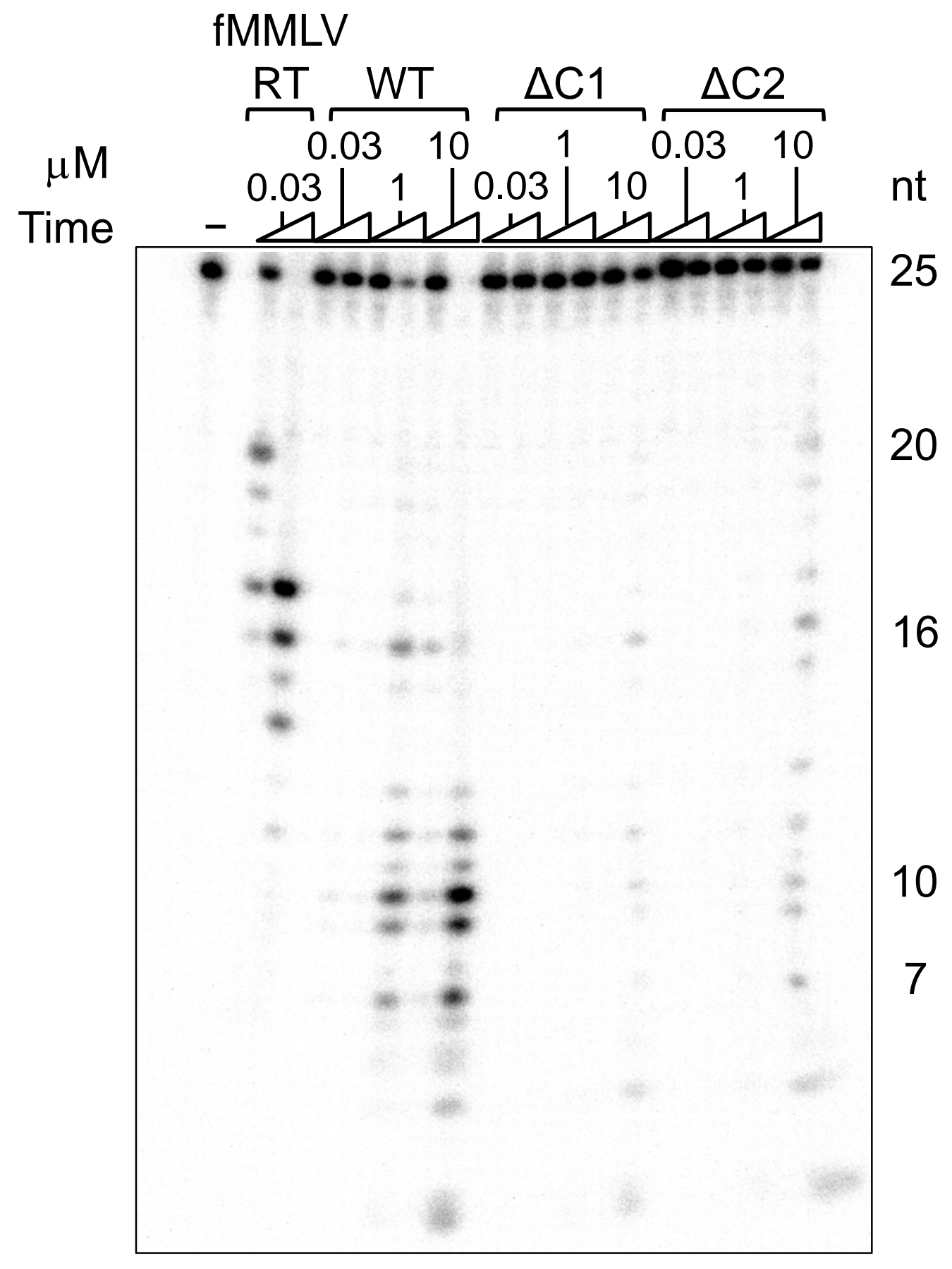

Fig. 5 


\section{C}

fMMLV RT WT

$\Delta \mathrm{C} 1$

$\Delta \mathrm{C} 2$

$(0.03 \mu \mathrm{M})$

$(1 \mu \mathrm{M}) \quad \mathrm{nt}$

$(10 \mu \mathrm{M})$

$(10 \mu \mathrm{M})$

nt

Time -

Time -

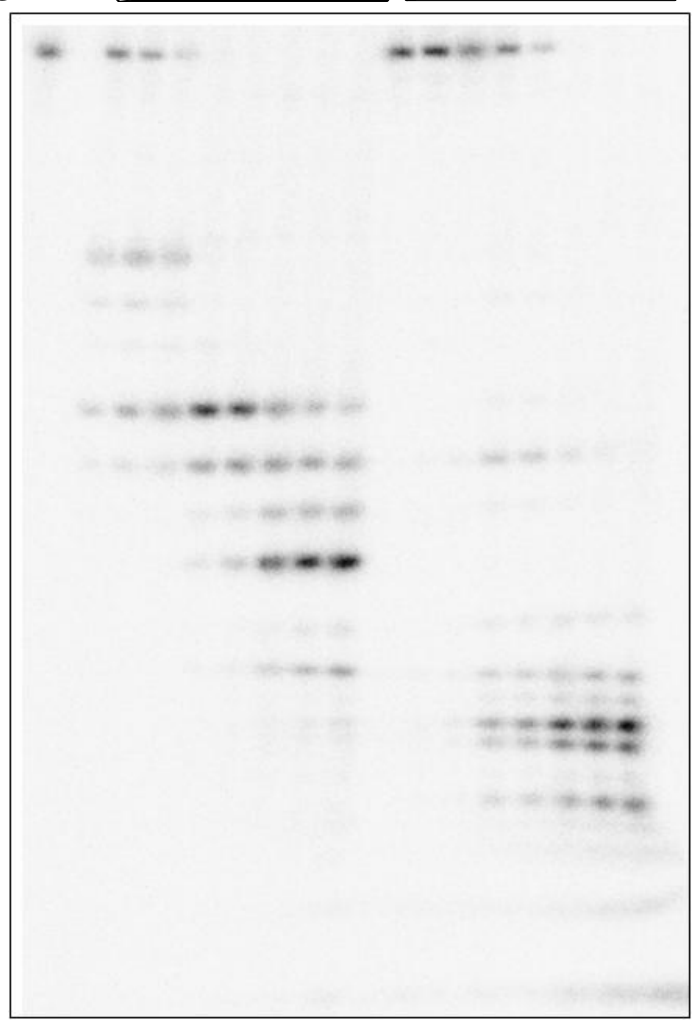

25

16

10

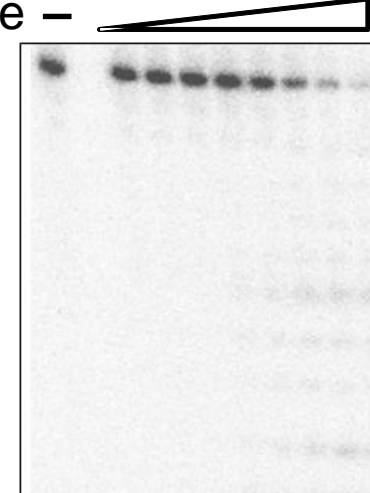

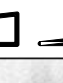

25

20
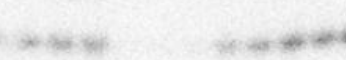

16

20

7

10

7

Fig. 5 

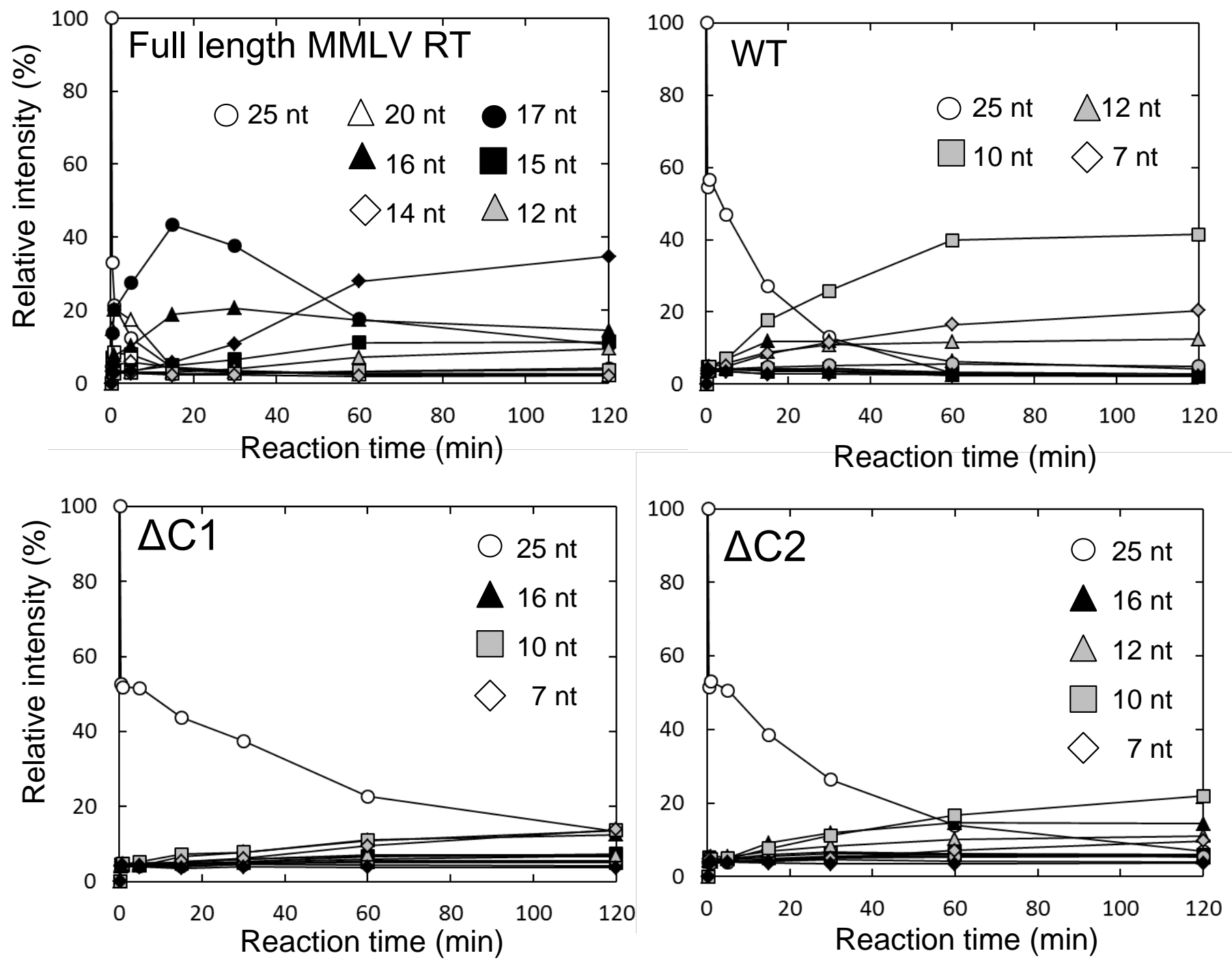

Fig. S1. Time course of the amounts of RNA fragments in the RNase $\mathrm{H}$ reaction. The result of the densitometry traces of the bands in Fig. 5C is shown. The relative intensity is defined as the ratio of the amount of each band to those of all 7-25-nt bands. Symbols for RNA fragments (nt): 25 (open circle), 20 (open triangle), 19 (open square), 18 (open diamond), 17 (solid circle), 16 (solid triangle), 15 (solid square), 14 (solid diamond), 13 (gray circle), 12 (gray triangle), 10 (gray square), and 7 (gray diamond). 